EUROPA REGIONUM TOM XXII ROK 2015

DOI: $10.18276 /$ er.2015.22-20

\author{
JAROSŁAW KLIMCZAK, MaŁgORZATA KLIMCZAK, ANETA OMELAN, \\ KAMIL KLIMCZAK \\ Olsztyn
}

\title{
Lotnisko regionalne szansa rozwoju turystyki na Warmii i Mazurach
}

\section{Wprowadzenie}

$\mathrm{N}^{2}$ a atrakcyjność regionu - zarówno turystyczną, jak i inwestycyjną - decydujący wpływ ma dostępność regionu oraz jakość infrastruktury transportowej. Szanse na rozwój regionu zależą zatem w dużej mierze od rozwiązania tego problemu.

Zły stan infrastruktury transportowej w Polsce hamuje wymianę międzynarodową z krajami UE i pozostałymi krajami sąsiadującymi, ogranicza możliwość przyciągnięcia kapitału zagranicznego i zmniejsza mobilność siły roboczej. Czynnik ten ma również wpływ na turystykę i może doprowadzić do ograniczenia dynamiki rozwoju turystyki w regionie, a wręcz do stopniowego osłabiania tego działu gospodarki regionalnej. Utrzymywanie się tak niekorzystnej sytuacji może wpłynąć na obniżenie konkurencyjności regionalnej gospodarki i stanowić barierę w procesach rozwojowych i innowacyjnych regionu.

Województwo warmińsko-mazurskie to region Polski, który obecnie jest słabo dostępny przede wszystkim ze względu na położenie na uboczu głównych linii komunikacyjnych oraz nie najlepszą infrastrukturę drogową. Dodatkowo sytuacji tej nie poprawiają koncepcje strategiczne dotyczące rozwoju autostrad oraz dróg ekspresowych w Polsce, które omijają region Warmii i Mazur. Dlate- 
go tak ważny i niezbędny staje się rozwój komunikacji lotniczej w regionie jako sposób na poprawę istniejącej sytuacji.

Warmia i Mazury to region o dużej atrakcyjności turystycznej, skłaniający do odwiedzin i spędzenia tutaj wolnego czasu. Szansą na rozwój regionu jest skuteczne rozwiązanie problemu jego dostępności zarówno dla mieszkańców Polski, jak i Unii Europejskiej oraz reszty świata. Rozwój transportu lotniczego jest gwarancją wzrostu dynamiki ruchu turystycznego w regionie, a także jego wzrostu gospodarczego.

Poniższe opracowanie stanowi próbę odpowiedzi na pytanie, w jaki sposób lotnisko regionalne może stać się czynnikiem warunkującym rozwój turystyki $\mathrm{w}$ regionie. Powstało ono w dużej mierze na podstawie prac analitycznych prowadzonych w latach 2004-2006, które jednak z powodu nieuruchomienia planowej inwestycji są aktualne do dzisiaj. W ramach obecnej perspektywy finansowej ze środków UE przeznaczono $37 \mathrm{mln}$ euro na rozbudowę infrastruktury lotniczej na terenie portu lotniczego w Szymanach, które powinny zostać wydane do 2015 roku ${ }^{1}$.

Zaproponowane $\mathrm{w}$ dalszej części artykułu rozwiązanie dotyczące utworzenia regionalnego operatora produktu turystycznego jest unikatowe w skali kraju, i po wdrożeniu w życie będzie mogło być wzorem do naśladowania przez inne regiony mające aspiracje $\mathrm{w}$ dziedzinie wykorzystania lotnisk regionalnych do rozwoju turystyki.

\section{Koncepcja wykorzystania portu lotniczego do rozwoju turysty- ki}

Lotnisko Szczytno-Szymany to jedyny pasażerski port lotniczy w północno-wschodniej Polsce. Port Szczytno-Szymany położony jest w centralnej części regionu, województwa warmińsko-mazurskiego, pośród wielkich kompleksów leśnych i jeziornych na Mazurach, zwanych Krainą Tysiąca Jezior, posiadających bogate zaplecze turystyczne.

Stolicą regionu jest Olsztyn, oddalony od lotniska o $58 \mathrm{~km}$. Do centrum miasta Szczytna to natomiast odległość $10 \mathrm{~km}$. W promieniu $70 \mathrm{~km}$ znajdują się

1 J. Klimczak, M. Żukowski, M. Klimczak, Perspektywy rozwoju ruchu turystycznego na Warmii i Mazurach poprzez wykorzystanie lotniska Szczytno-Szymany, Warszawa 2011. 
takie atrakcyjne ośrodki turystyczne, jak: Mrągowo, Mikołajki, Giżycko, Ruciane-Nida oraz Kętrzyn.

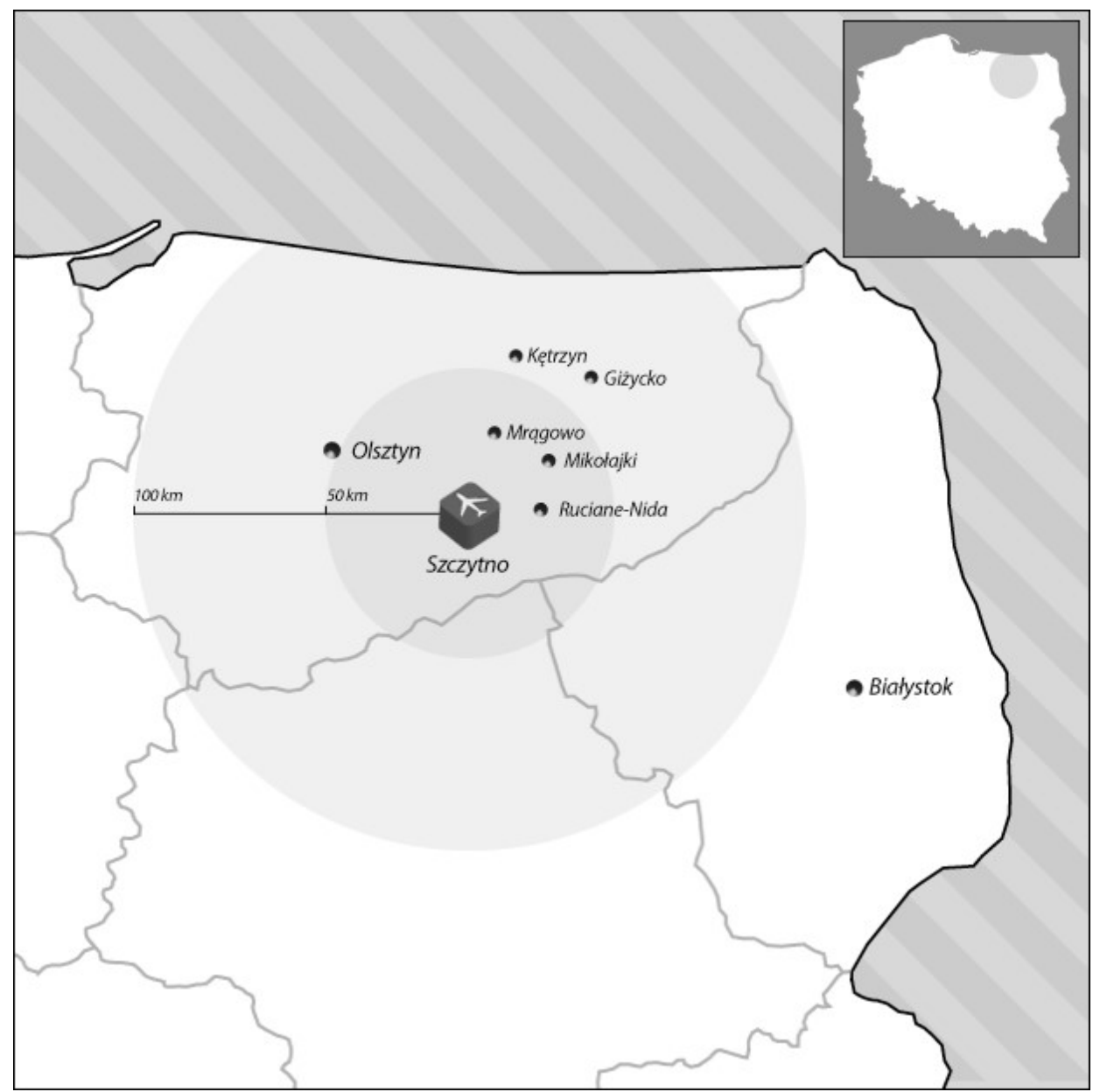

Rys. 1. Położenie lotniska Szczytno-Szymany oraz obszar jego bezpośredniego oddziaływania

Źródło: opracowanie własne.

Rozbudowa portu lotniczego i uruchomienie działalności lotniczej będzie miało na celu: 
- rozwój turystyki w województwie warmińsko-mazurskim poprzez ułatwiony dostęp turystów krajowych i zagranicznych do północno-wschodniej części Polski,

- wskazanie możliwości rozwoju turystyki na Warmii i Mazurach w oparciu o istniejącą infrastrukturę lotniczą oraz określenie możliwości dalszego rozwoju lotniska poprzez obsługę tanich lotów oraz lotów czarterowych,

- wykreowanie pozycji lotniska jako regionalnego centrum transportu turystycznego,

- podjęcie współpracy wszystkich podmiotów zainteresowanych rozwojem regionu - władz wojewódzkich, samorządowych, organizacji i stowarzyszeń oraz podmiotów komercyjnych działających w branży turystycznej.

Warmia i Mazury to region o dużej atrakcyjności turystycznej, skłaniający do odwiedzin i spędzenia tutaj wolnego czasu. Wraz z rozwojem w Europie transportu lotniczego i jego wzrastającego znaczenia jako sposobu obsługi ruchu turystycznego, daje się zauważyć silny wpływ tego czynnika na atrakcyjność turystyczną regionu ${ }^{2}$.

Coraz większego znaczenia nabiera czas, i w tym kontekście transport lotniczy wychodzi naprzeciw oczekiwaniom rynku.

Poza tym należy mieć na uwadze efekty, jakie dla gospodarki regionalnej przyniesie uruchomienie lotniska - generowanie nowych miejsc pracy (a więc zmniejszenie bezrobocia), napływ nowych inwestycji i kapitału (a więc podniesienie atrakcyjności inwestycyjnej regionu), wzrost społeczno-gospodarczy regionu.

Lotnisko ma stać się stymulatorem rozwoju regionu, a poprzez zwiększony i ułatwiony dostęp turystów krajowych i zagranicznych do Warmii i Mazur ma przyczynić się do rozwoju turystycznego regionu.

Lotnisko Szczytno-Szymany ma stać się portem lotniczym dla całego regionu Warmii i Mazur, stąd istotne jest używanie nazwy dla portu, która będzie identyfikowała cały obszar i plasowała go w umyśle konsumenta. Nazwa własna Port Lotniczy „MAZURY” wydaje się właściwa z punktu widzenia promocji całego regionu. Jest to poza tym hasło kojarzone i rozpoznawalne przez potencjalne grupy odbiorców oferty.

Transport lotniczy można podzielić na dwie zasadnicze grupy:

2 W odniesieniu do „Strategii rozwoju sieci drogowej regionu warmińsko-mazurskiego” opracowanej przez Instytut Badawczy Dróg i Mostów w Warszawie. 
- transport komercyjny, który obejmuje:

- transport pasażerski (rejsowy oraz czarterowy) oraz

- transport towarowy,

- transport niekomercyjny:

- general aviation - lotnictwo ogólne.

Z punktu widzenia kreowania ruchu turystycznego na Warmii i Mazurach, największe znaczenie ma komercyjny transport pasażerski oraz część lotnictwa ogólnego (general aviation), związanego z tzw. „taksówkami powietrznymi”. Dlatego najsilniejszy akcent należy postawić na rozwiązania strategiczne dotyczące kwestii stymulowania wzrostu tego ruchu. Pozostałe obszary zostały jedynie zasygnalizowane jako ważne przy budowaniu biznes planu dla Portu Lotniczego „MAZURY”.

\subsection{Transport pasażerski}

Ze względu na charakter regionu dominującym celem podróży pasażerów obsługiwanych przez port lotniczy „MAZURY” będzie turystyka oraz wypoczynek. Biznes, tranzyt oraz inne cele stanowić będą znacznie mniejszy udział w ogólnej liczbie obsłużonych pasażerów.

Taka struktura profilu podróżnych podyktowana jest położeniem geograficznym lotniska, bliskością Warmii i Mazur, które ze względu na bogactwo przyrodnicze oraz możliwości, jakie stwarzają do aktywnego spędzania wolnego czasu, łączą ten region z turystyką i wypoczynkiem. W związku z powyższym najistotniejszym obszarem związanym z kreowaniem ruchu, będzie turystyka.

W tym kontekście niezwykle istotny staje się obszar stymulowania i rozwijania lotniczego ruchu turystycznego, nawiązania współpracy z tanimi liniami lotniczymi, przewoźnikami czarterowymi, dużymi touroperatorami zagranicznymi, biurami podróży. Kluczowe staje się również podjęcie współpracy z instytucjami, organizacjami oraz osobami prywatnymi działającymi bezpośrednio w regionie, a które są właścicielami bazy, tworzą lub kreują ofertę turystyczną Warmii i Mazur. Od zintegrowania działań i wysiłków podejmowanych przez te wszystkie podmioty zależy bowiem sukces funkcjonowania lotniska oraz wzrost lotniczego ruchu turystycznego w porcie „MAZURY”.

Rozwój ruchu turystycznego powinien odbywać się poprzez rozwój ruchu czarterowego (ruch nieregularny) oraz docelowo również poprzez uruchomienie 
połączeń regularnych $\mathrm{z}$ wybranymi najważniejszymi stolicami europejskimi, a także z wybranymi regionami Polski. Oba rodzaje połączeń będą obsługiwane w przeważającej części przez tanie linie lotnicze.

W odniesieniu do rozwoju komunikacyjnego ruchu krajowego rozwój połączeń regularnych powinien opierać się głównie na połączeniach z Wrocławiem, Poznaniem, Katowicami oraz Krakowem (z częścią południową i południowo-zachodnią Polski). Wynika to $\mathrm{w}$ dużej mierze $\mathrm{z}$ usytuowania portu „MAZURY” w sąsiedztwie dwóch ważnych lotnisk: Warszawy i Gdańska, stąd też prawdopodobnie połączenia $\mathrm{z}$ nimi będą miały raczej marginalne znaczenie $^{3}$.

Z punktu widzenia rozwoju komunikacyjnego ruchu międzynarodowego należałoby jednak rozważyć uruchomienie w porcie „MAZURY” połączeń regularnych z Warszawą. Uruchomienie takiego połączenia pozwoliłoby na rozwój lotniska i całego regionu. Poprzez Warszawę województwo warmińsko-mazurskie miałoby połączenia lotnicze niemal z całym światem.

\subsection{Transport towarowy}

Uzupełnienie działalności lotniska stanowić powinien transport towarowy, tzw. cargo. Stanowić będzie ono jednak prawdopodobnie niewielki procent ogółu operacji lotniczych dokonywanych w porcie. Będzie miał jednak wpływ na poprawę działalności ekonomicznej lotniska.

Cargo może być ponadto wykorzystywane do transportu żywności ekologicznej z regionu na rynki europejskie, gdzie produkty polskie cieszą się ogromnym uznaniem.

W planach organizacji przestrzeni wokół lotniska jest uruchomienie Specjalnej Strefy Ekonomicznej. Uruchomienie strefy w bezpośrednim sąsiedztwie lotniska mogłoby spowodować lokowanie się w obrębie strefy prywatnego biznesu. Napływ inwestycji, w tym zagranicznych, dałby impuls dla rynku pracy.

3 Zgodnie $\mathrm{z}$ „Założeniami planu rozwoju infrastruktury komunikacji lotniczej $w$ województwie warmińsko-mazurskim" opracowanymi przez Zespół Roboczy ds. Infrastruktury Lotniczej, Olsztyn, kwiecień 2004. 


\subsection{Transport niekomercyjny}

Ruch general aviation to tzw. lotnictwo ogólne i prac powietrznych, czyli wszystko to, co nie jest komercyjnym transportem liniowym, pasażerskim oraz towarowym ${ }^{4}$.

General aviation to zatem:

- podróże służbowe,

- loty szkolne i instruktażowe,

- loty przy pracach agrolotniczych,

- loty lotniczego pogotowia ratunkowego,

- loty służb, takich jak: straż pożarna, policja, służby celne, patrole służb granicznych oraz

- indywidualne loty turystyczne.

Lotnictwo ogólne to także tzw. latające taksówki - czyli lokalny transport powietrzny. „Latające taksówki” mogą być wykorzystywane do pasażerskich połączeń lotniczych z i do mniejszych miast, miejscowości regionu, tam gdzie nie ma regularnych połączeń lotniczych. Prywatne samoloty i helikoptery pasażerskie mogą dotrzeć wszędzie i o każdej porze, według rozkładu lotów, które układa podróżujący, a nie linie lotnicze. „Latające taksówki” są również często wykorzystywane do przesyłek towarowych ze względu na ogromną elastyczność takiej formy transportu w stosunku do nadającego przesyłkę.

System rozwoju lokalnych połączeń lotniczych w regionie powinien być realizowany w oparciu o system lokalnych lotnisk i lądowisk.

\subsection{Działania warunkujace powodzenie projektu}

Aby jednak wszystkie ww. elementy miały szansę na spełnienie i zrealizowanie, niezbędne jest:

a) czynne uruchomienie portu lotniczego;

b) powołanie Biura Promocji „MAZURY” działającego przy spółce lotniczej wyraźne rozdzielenie funkcji lotniskowej oraz promocyjnej (jeżeli chodzi o strukturę), przy jednoczesnym zachowaniu ścisłej zależności między rozwojem obu działalności. Biuro miałoby zająć się działaniami związanymi

4 R.K. Mitchell, B.R. Agle, D.J. Wood, Toward a Theory of Stakeholders, Academy of Management Review, t. 22, 1997. 
$\mathrm{z}$ kreowaniem turystycznego ruchu lotniczego $\mathrm{w}$ regionie oraz promocją turystyczną województwa i samego lotniska, kontaktami z dużymi zagranicznymi touroperatorami, biurami podróży oraz branżą turystyczną działającą $\mathrm{w}$ regionie;

c) zgodność i wola współpracy decydentów regionalnych (właścicieli lotniska - lotniczej spółki zarządzającej) w kierunku rozwoju lotniska;

d) ścisła współpraca spółki lotniczej oraz biura promocyjnego - wspólne wypracowywanie operacyjnych planów działania na dany rok, uzgodnienia co do kierunków uruchamiania połączeń lotniczych, tak by podejmowane działania promocyjne regionu odpowiadały rzeczywistej ofercie usług lotniska. Współpraca i przepływ informacji jako warunek powodzenia podejmowanych działań marketingowych powinien obejmować:

e) wprowadzenie systemowych rozwiązań dotyczących komunikacji lotniska z regionem - zwiększenie dostępności poprzez:

- rozwiązanie problemu dostępności drogowej - modernizacja istniejących dróg oraz zapewnienie bezpiecznego i stałego skomunikowania lotniska $\mathrm{z}$ regionem,

- stworzenie systemu komunikacji lotniczej wewnątrz regionu - skomunikowanie lotniska w Szymanach z portami i lądowiskami lokalnymi,

f) włączenie branży oraz stowarzyszeń i organizacji turystycznych działających w regionie, ze szczególnym uwzględnieniem ROT (Regionalnej Organizacji Turystycznej) w proces kreowania oferty turystycznej regionu. ROT to podmiot „spinający” podejmowane w regionie inicjatywy dotyczące sektora turystyki, pozyskujący i dystrybuujący środki unijne na promocję oraz integrator budowania regionalnej oferty turystycznej.

\subsection{Podmioty niezbędne w systemie zarządzania ruchem tury- stycznym w regionie}

Funkcjonowanie portu lotniczego wymaga istnienia:

- infrastruktury lotniczej - całość infrastruktury umożliwiającej sprawną obsługę samolotów oraz pasażerów,

- podmiotu zarządzającego lotniskiem - przedsiębiorstwo posiadające odpowiednie certyfikaty wraz z prowadzeniem usług towarzyszących i okołolotniczych, 
- podmiotu promocyjnego - struktura organizacyjna zajmująca się promocją i marketingiem ruchu turystycznego $\mathrm{w}$ oparciu o lotnisko oraz sprzedaż usług dla turystów korzystających z transportu lotniczego.

Uwzględniając oddziaływanie wszystkich grup partnerów rynkowych, poniżej określone zostały główne warianty utworzenia spółki marketingowej, jakie były rozpatrywane $\mathrm{w}$ trakcie tworzenia dokumentu. Każdy $\mathrm{z}$ wariantów ma swoje mocne i słabe strony, wybór jednego z nich będzie podyktowany decyzjami politycznymi, uzgodnieniem stanowiska pomiędzy najważniejszymi partnerami oraz zasobami finansowymi

\section{Warianty właścicielskie utworzenia spółki marketingowej}

\subsection{Działalność promocyjna podlegająca wyłącznemu nadzorowi spółki lotniczej}

Wariant ten zakłada wyłączny nadzór i wpływ na działalność podmiotu promocyjnego przez spółkę lotniczą. Opcje te można zrealizować poprzez utworzenie działu zajmującego się promocją wewnątrz spółki lotniczej albo przez utworzenie nowego, zależnego podmiotu. Podobne rozwiązania są stosowane w innych spółkach lotniczych obsługujących regionalne porty lotnicze. Nie uwzględniają one jednak turystycznego charakteru regionu.

Zaletą jest brak konieczności negocjacji pomiędzy partnerami tworzącymi taki podmiot, podejmowanie szybkich decyzji i zapewnienie podstawowych usług dla obsługi pasażerów.

Wadą takiego rozwiązania jest koncentracja wyłącznie na działaniach związanych ze sprzedażą biletów lotniczych. Można przyjąć, że podmiot promocyjny będzie koncentrował się wyłącznie na zapewnieniu obsługi dla spółki lotniczej, bez budowania ściślejszych powiązań z branżą turystyczną w regionie. Wymagać też będzie finansowania, szczególne na początku działalności, wyłącznie przez spółkę zajmującą się obsługą lotniska. Ponadto na spółce lotniczej spoczywać będzie konieczność budowy struktury i doboru kadr dla działań znacznie przekraczających typową obsługę promocyjną portu lotniczego. 


\subsection{Działalność promocyjna podlegająca wyłącznemu nadzorowi Regionalnej Organizacji Turystycznej}

W tym wariancie zakłada się utworzenie spółki promocyjnej przez Regionalną Organizację Turystyczną. Poprzez ROT pośredni wpływ na spółkę będzie miała większość wiodących interesariuszy rynku turystycznego: Urząd Marszałkowski, samorządy oraz branża turystyczna. Pozwoli to na promocję oferty turystycznej regionu i sprzedaż gotowych pakietów.

Spółka taka powinna być powiązana ze spółką lotniczą za pośrednictwem długoterminowej umowy regulującej zasady współpracy i zakres działań obydwu podmiotów. Związek z ROT zapewni spółce udział w akcjach promocyjnych ROT.

Wadą jest brak bezpośredniego wpływu na działalność podmiotu promocyjnego ze strony spółki lotniczej oraz brak interesu w rozwoju jej działalności. Sytuacja ta stwarza też potencjalne niebezpieczeństwo dla spółki lotniczej utraty bezpośredniej kontroli nad działaniami związanymi z tworzeniem popytu na usługi lotnicze. Oddziaływanie wyłącznie ze strony branży może koncentrować działalność jedynie na tworzeniu produktów i zwiększaniu sprzedaży podmiotów turystycznych regionu.

Ponadto ROT może mieć trudności z operacyjnym zarządzaniem spółką ze względu na braki kadrowe oraz brak doświadczenia w organizowaniu takich przedsięwzięć.

\subsection{Spółka promocyjna, której właścicielem jest inwestor komer- cyjny}

Wariant ten przewiduje utworzenie podmiotu promocyjnego przez inwestora komercyjnego. Można to zrealizować poprzez powierzenie tej działalności jednemu podmiotowi lub wyborze kilku partnerów. Podmioty takie świadczyłyby usługi związane ze sprzedażą oferty turystycznej i zwiększaniem ruchu lotniczego. Podmiot taki powinien być powiązany umową ze spółką lotniczą, która określi zasady świadczenia usług przez podmiot marketingowy i relacje ze spółką lotniczą.

Zaletą tego rozwiązania jest komercjalizacja działalności, a co za tym idzie duża skuteczność oraz posiadanie wiedzy oraz zaplecza ludzkiego i techniczne- 
go dla takiej działalności. Poza tym nie pociągałoby to za sobą nakładów na tworzenie spółki ze strony podmiotów publicznych.

Podmiot komercyjny jest jednak zainteresowany optymalizacją przychodów i zysków z działalności, co mogłoby wpłynąć na ograniczanie realizacji misji publicznej spółki. Poza tym powierzanie strategicznego obszaru działań dla całego regionu podmiotowi komercyjnemu może prowadzić do utraty kontroli nad promocją i sprzedażą pakietów turystycznych, wykorzystaniem środków publicznych na promocję poprzez podmiot komercyjny.

\subsection{Spółka promocyjna w formule partnerstwa publiczno- -prywatnego}

Wariant ten jest połączeniem mocnych stron poprzednich rozwiązań. Zakłada on połączenie interesów i współpracę podmiotów na zasadach partnerstwa publiczno-prywatnego.

Jego wadą jest duży nakład prac związany z tworzeniem przedsięwzięcia, określeniem konsensusu pomiędzy głównymi partnerami.

Ze względu na strategiczny charakter prowadzonej działalności oraz publiczny, jak i komercyjny charakter działań, proponuje się utworzenie podmiotu przez spółkę lotniczą, zarządzającą portem lotniczym, Regionalną Organizacją Turystyczną oraz inwestora komercyjnego.

Dzięki temu spółka lotnicza, a poprzez nią władze województwa, będą miały strategiczny wpływ na działalność promocyjną, zwiększającą ruch lotniczy w regionie. Pozwoli to także na stabilną współpracę pomiędzy spółką lotniczą i marketingową. Zabezpieczy to interesy strategiczne portu lotniczego.

Wariant ten umożliwi również zabezpieczanie interesów promocji regionu i rozwój branży turystycznej. ROT jako udziałowiec zapewni kontrolę i wpływ ze strony sektora publicznego i przedsiębiorstw turystycznych. Pozwoli to również na bezpieczne wykorzystanie funduszy na promocję ze środków UE. Koordynacja i współpraca ze strony ROT pozwoli na budowę dobrych stosunków spółki z samorządami i podmiotami gospodarczymi.

Podmiot komercyjny, będący partnerem w przedsięwzięciu, uzyska unikalne możliwości tworzenia i sprzedaży pakietów pobytowych w obiektach, promocji oferty oraz stabilnych podstaw funkcjonowania w oparciu o umowy z partnerami. 
Wariant ten umożliwi optymalizację i najszerszy zakres działań spółki promocyjnej. Budowa trwałych podstaw i konsekwentne prowadzenie promocji jest niezbędnym, jednym z najistotniejszych elementów całej strategii, który zaważy o jej powodzeniu i dlatego autorzy opracowania rekomendują go jako optymalny wariant do wdrożenia $\mathrm{w}$ regionie.

Strategicznymi etapami rozwoju spółki marketingowej działającej przy lotnisku w tym wariancie jest:

- utworzenie spółki lotniczej i zgoda na udział w realizacji projektu,

- zgoda władz regionalnych i samego ROT na udział w przedsięwzięciu,

- uzgodnienia pomiędzy Urzędem Marszałkowskim, ROT i spółka lotniczą,

- określenie warunków, jakie powinien spełniać partner komercyjny,

- znalezienie partnera komercyjnego dysponującego zasobami ludzkimi, know-how i zapleczem technicznym,

- negocjacje i podpisanie umowy partnerskiej,

- utworzenie spółki promocyjnej,

- podpisanie umowy pomiędzy spółką lotniczą i promocyjną,

- uruchomienie działalności. 


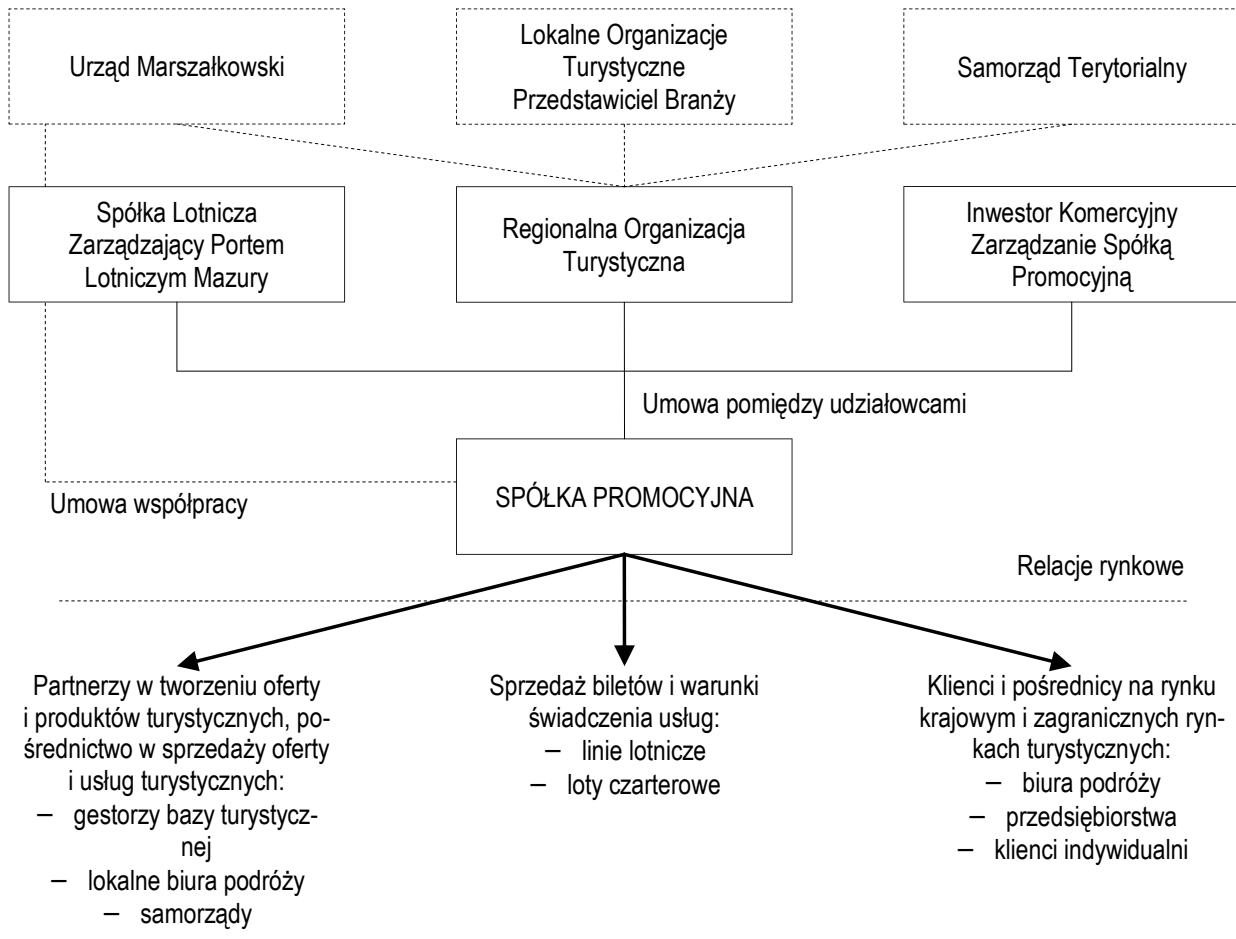

Rys. 2. Schemat relacji dotyczący rozwoju spółki promocyjnej w formule partnerstwa publiczno-prywatnego

Źródło: opracowanie własne.

\section{Formuła funkcjonowania oraz obszar działalności Biura Pro- mocji "MAZURY"}

Formuła funkcjonowania Biura Promocji osadza się na wyraźnym oddzieleniu w strukturze organizacyjnej lotniska działalności lotniczej od marketingowej związanej z promocją i kreowaniem ruchu.

Za część promocyjną odpowiadać ma właśnie Biuro Promocji. Obszar zarządzania działalnością lotniskową pozostaje w gestii spółki zarządzającej lotniskiem.

Oba rodzaje działalności muszą jednak bardzo ściśle ze sobą współpracować, aby możliwe było odniesienie sukcesu rynkowego. Biuro Promocji „MAZURY” ma działać na zasadach rynkowych, tzn. ma utrzymywać się samodzielnie - generować zyski. W związku z powyższym formuła własnościowa biura, obszar i zakres działalności oraz system relacji z organizacjami i podmio- 
tami turystycznymi działającymi w regionie muszą stwarzać najlepsze, najoptymalniejsze warunki do rozwoju biura. Formuła funkcjonowania stwarzać również powinna najlepsze warunki do rozwoju gospodarki turystycznej w regionie, stymulować rozwój, dawać impuls dla nowych inicjatyw turystycznych i gospodarczych na Warmii i Mazurach.

Współpraca pomiędzy spółką zarządzającą lotniskiem a Biurem Promocji jest tym ważniejsza, że jakość relacji pomiędzy obiema działalnościami przekładać się będzie na zadowolenie klientów, a tym samym na jakość usług. Spółka zarządzająca lotniskiem powinna bowiem aktywnie reagować na wszelkie sygnały docierające z rynku, dotyczące jakości obsługi swoich klientów podróżnych, przewoźników. Za kontakty z klientami lotniska w dużej mierze odpowiadać będzie, zgodnie z zakresem zadań, właśnie Biuro Promocji, i dlatego tak ważna jest ścisła współpraca obu komórek.

\subsection{Zadania Biura Promocji „MAZURY”}

Biuro Promocji będzie miało za zadanie stymulowanie ruchu turystycznego na Mazury w oparciu o wykorzystanie komunikacji lotniczej na poziomie międzynarodowym, jak i regionalnym, wykorzystując lokalne lotniska oraz lądowiska (wspieranie marketingowe utworzenia sieci współpracujących ze sobą lotnisk i lądowisk lokalnych).

Biuro zajmować się będzie budowaniem kompleksowej oferty turystycznej, wykorzystującej transport lotniczy. Będzie zatem samodzielnie tworzyć pakiety programowe lub sprzedawać gotowe pakiety przygotowane przez lokalne organizacje turystyczne, lokalne biura podróży lub inne podmioty zainteresowane rozwojem turystyki na Mazurach. Poznając rynek, nawiązując szerokie kontakty międzynarodowe zarówno z tanimi przewoźnikami, jak i touroperatorami, Biuro będzie mogło tak profilować ofertę oraz standard oferowanych usług, by jak najlepiej dopasować ofertę do wymagań i potrzeb klientów. Ścisła współpraca ze spółką zarządzającą lotniskiem oraz partnerami regionalnymi i lokalnymi jest gwarantem powodzenia projektu.

Biuro zarabiać będzie na prowizji od sprzedaży oferty regionu. Sprzedaż oferty będzie poprawiała sytuację lotniska, napędzała koniunkturę gospodarczą dla regionalnego rynku turystycznego, stymulowała inwestycje, czyli wpływała na rozwój regionu.

Zadania Biura określone zostały zatem jako: 
1. Tworzenie i sprzedaż pakietów turystycznych - na Warmii i Mazurach, wzorem dobrze rozwiniętych turystycznie krajów; nastąpić powinna, zapoczątkowana dobrą kampanią promocyjną, sprzedaż oferty turystycznej regionu. Biuro Promocji pakiety będzie tworzyło samodzielnie lub sprzedawać będzie gotowe pakiety przygotowane przez lokalne biura podróży oraz inne podmioty. Biuro będzie miało zatem również funkcję pośrednika w sprzedaży oferty Warmii i Mazur - ze względu na większą siłę przebicia wśród dużych touroperatorów zagranicznych oraz tanich przewoźników oraz ze względu na efekt skali.

Najistotniejsze założenia do tworzenia pakietów turystycznych i kreacji oferty programowej dla Warmii i Mazur to, poza rozwojem tradycyjnej oferty wypoczynku letniego (pakiety 1-2 tygodniowe):

- rozwój oferty całorocznej - rozwój programów i pakietów całorocznych w oparciu o zasoby regionu - korelacja z ważnymi wydarzeniami kulturalnymi oraz sportowymi odbywającymi się w województwie, a także rozwijanie oferty w kierunku przyciągnięcia nowych klientów,

- rozwój pakietów weekendowych - zorganizowanych wycieczek 1-2 dniowych, oferujących ofertę kompleksową od przyjazdu po turystę do miejsca zakwaterowania, poprzez zapewnienie ciekawego programu wycieczki, po transfer turystów z powrotem do miejsca noclegu; kreowanie wizerunku Warmii i Mazur jako doskonałego miejsca na wypady weekendowe przez cały rok (uruchomienie lotniska - skrócenie czasu podróży pozwoli turyście, szczególnie zagranicznemu, na przyjazdy na Warmię i Mazury również na krótkie okresy 2-3 dniowe - stymulowanie dodatkowego ruchu).

2. Promocja Mazur - kreowanie i stymulowanie ruchu turystycznego na Warmię i Mazury. Sprzedaż oferty regionu w powiązaniu z lotniskiem (zwiększona dostępność) pozwoli na uaktywnienie turystyczne Mazur przez cały rok.

3. Zapewnienie transferu z lotniska do miejsca docelowego - Biuro dbać będzie o zapewnienie transferu podróżnego $\mathrm{z}$ lotniska do miejsca docelowego lub do węzła komunikacyjnego (przesiadkowego) w ramach sprzedaży swoich pakietów. Transfer podróżnego z lotniska będzie bowiem w gestii spółki zarządzającej lotniskiem, która będzie mogła zlecić obsługę podróżnego z lotniska do miejsca docelowego firmie zewnętrznej, nie musi być nią jednak Biuro Promocji. 
4. Aktywne współdziałanie w zakresie promocji turystyki w regionie na styku samorząd-branża turystyczna. Wspólne z samorządem i branżą turystyczną województwa warmińsko-mazurskiego działanie w kierunku promocji regionu, wzrostu liczby podróżnych, wzrostu inwestycji oraz kreowania atrakcyjnej oferty turystycznej (całorocznej).

Aby jednak zadania stawiane przed Biurem dotyczące uaktywnienia ruchu turystycznego na lotnisku MAZURY mogły zostać zrealizowane, nastąpić musi duża kampania promocyjna Warmii i Mazur, ukierunkowana na zmianę obecnego sposobu postrzegania regionu, jak również sprofilowania oferty dostosowanej dla klienta linii lotniczych. Województwo jest bowiem postrzegane jako słabo dostępne. Nastąpić musi zatem promocja lotniska MAZURY jako węzłowego lotniska regionalnego wraz z kompleksową ofertą turystyczną rozpoczynającą się od przylotu do Szyman, poprzez zapewnienie szybkiego transferu do miejsca przeznaczenia (docelowego pobytu), zapewnienie podstawowej oferty (nocleg, wyżywienie) oraz atrakcji dodatkowych (programy, wycieczki alternatywne), aż po transfer powrotny na lotnisko i przelot do miejsca zamieszkania.

Biuro Promocji „MAZURY” działające przy lotnisku w Szymanach będzie mieć na celu kreowanie i stymulowanie ruchu turystycznego na Warmii i Mazurach. Biuro ma stymulować popyt na usługi lotnicze i kreować wizerunek województwa jako regionu, do którego można dotrzeć SZYBKO, TANIO, WYGODNIE i BEZPIECZNIE. A więc ma za zadanie zmianę obecnego wizerunku regionu, który łączył się z uciążliwą, długą podróżą samochodem lub autokarem, krętymi drogami o nienajlepszej nawierzchni.

\subsection{Działania warunkujace powodzenie funkcjonowania Biura}

1. Kompetentny zespół fachowców (pracowników Biura Promocji), znających rynek turystyczny, rynek touroperatorski, rynek pośredników oraz dobrze znających region Warmii i Mazur. Zespół ten musi charakteryzować się wysokimi kompetencjami w obszarze marketingu, promocji, budowania oferty, komunikacji i negocjacji, zarządzania marką oraz znać języki obce.

2. Długofalowa relacja współpracy pomiędzy Biurem Promocji „MAZURY” a spółką zarządzającą lotniskiem oparta na jasno określonych zasadach. Pozwoli to na zrealizowanie zakładanych celów oraz zapewni ciągłość i przejrzystość działania. 
3. Integracja działań promocyjnych podejmowanych w województwie (styk samorząd-branża turystyczna). Niezbędna jest tutaj ścisła współpraca wielu podmiotów odpowiedzialnych za kształtowanie wizerunku regionu oraz za kształt oferty turystycznej. Są to w szczególności:

- Urząd Marszałkowski Województwa Warmińsko-Mazurskiego,

- samorządy gminne województwa warmińsko-mazurskiego,

- Warmińsko-Mazurska Regionalna Organizacja Turystyczna,

- branża turystyczna działająca w województwie oraz samorządy (biura podróży, firmy turystyczne, właściciele bazy noclegowej, gastronomicznej, atrakcji, organizatorzy imprez itp.).

4. Aktywny udział Regionalnej Organizacji Turystycznej w działalności Biura, zapewniającej stały i bieżący kontakt z branżą turystyczną oraz samorządami. ROT jako beneficjent środków strukturalnych na promocję regionu dawałby gwarancję dobrego wykorzystania pozyskanych funduszy.

5. Aktywne i prawidłowe relacje pomiędzy wszystkimi interesariuszami i partnerami Biura.

\subsection{Główni interesariusze oraz partnerzy Biura Promocji "MAZURY"}

Powołanie Biura Promocji „MAZURY” powinno być rozpatrywane w kategoriach narzędzia, które czemuś, komuś służy. Jak zdefiniować to „coś” (cel, interes, oczekiwanie) i zidentyfikować tego „kogoś” (stakeholder czyli interesariusz) oraz określić, czy i jakie relacje istnieją, powinny istnieć pomiędzy nimi?

Definicji pojęcia interesariusz jest wiele. Przyjmujemy tu, że jest nim podmiot, który jest lub może być pod wpływem, wpływa lub może potencjalnie wpływać na daną organizację.

Główni interesariusze oraz partnerzy Biura Promocji zostali określeni jako:

a) Warmińsko-Mazurska Regionalna Organizacja Turystyczna (ROT);

b) Lokalne Organizacje Turystyczne województwa warmińsko-mazurskiego (LOT-y);

c) gestorzy indywidualni (osoby prywatne oraz samorząd) - właściciele bazy noclegowej, gastronomicznej, atrakcji turystycznych, organizatorzy imprez. 
d) firmy transportowe (państwowe i prywatne) - zapewniające transfer z lotniska do miejsca docelowego lub dogodnego punktu przesiadkowego $\mathrm{w}$ ramach sprzedanych pakietów;

e) spółka lotnicza - spółka zarządzająca lotniskiem;

f) touroperatorzy, biura podróży polskie i zagraniczne.

\subsection{Relacje $z$ głównymi partnerami, interesariuszami Biura Pro- mocji}

Biuro Promocji „MAZURY” będzie miało funkcję integratora wszelkich inicjatyw regionalnych i lokalnych podejmowanych $\mathrm{w}$ regionie, aktywnie współpracującego z organami samorządowymi, instytucjami oraz podmiotami prywatnymi w kierunku promowania i sprzedaży oferty turystycznej Warmii i Mazur, w tym kompleksowych pakietów turystycznych.

Główni partnerzy, interesariusze Biura Promocji oraz relacje pomiędzy podmiotami:

1. Warmińsko-Mazurska Regionalna Organizacja Turystyczna (ROT):

- promocja lotniska poprzez promowanie regionu - działanie realizowane w ramach projektu promocyjnego; promowanie kompleksowych rozwiązań komunikacji lotniczej podejmowanych w regionie, w tym rozwiązań lotniczej komunikacji „taksówkowej” jako elementu wychodzącego naprzeciw oczekiwaniom turysty - otwarcie regionu na potrzeby turystów, wprowadzanie nowych rozwiązań, by ułatwić turyście dotarcie na Mazury, pozwalając tym samym na dłuższy pobyt na miejscu (skrócenie czasu i uciążliwości podróży); wspólna promocja lotniska oraz regionu (lotnisko jako część Warmii i Mazur) podczas targów turystycznych, szczególnie targów zagranicznych (udostępnianie powierzchni wystawienniczej) dotarcie do klienta „hurtowego”, uaktywnienie połączeń czarterowych,

- promowanie połączeń regularnych - profil promocji skierowany do klienta indywidualnego; lotnisko poza ruchem nieregularnym powinno docelowo starać się uruchomić regularne połączenia lotnicze z najważniejszymi stolicami europejskimi oraz wybranymi miastami w kraju. ROT powinna aktywnie wspierać działania promocyjne podejmowane w zakresie uruchomienia tanich regularnych połączeń,

- promocja Biura - promowanie i zachęcanie podmiotów lokalnych do włączania się w projekt, do aktywnej współpracy z Biurem, do zgłaszania 
produktów turystycznych, które mogą być włączane w pakiety ofertowe. Uwiarygodnienie Biura $\mathrm{w}$ oczach lokalnych podmiotów, nadanie rangi,

- promocja przez Internet - zapewnienie przez ROT Biuru Promocji możliwości sprzedaży oferty Biura on-line - zwiększenie dostępności oferty.

2. Lokalne Organizacje Turystyczne (LOT-y):

- tworzenie regionalnych i lokalnych pakietów turystycznych - współtworzenie oferty turystycznej sprzedawanej w formie pakietów przez Biuro Promocji,

- kontakty z lokalnymi władzami, lokalnymi gestorami - LOT-y jako integrator inicjatyw lokalnych oraz podmioty koordynujące działania promocyjne w regionie,

- tworzenie imprez - kreowanie imprez wizerunkowych o charakterze promocyjnym.

3. Gestorzy indywidualni (osoby prywatne oraz samorząd):

- sprzedaż oferty - sprzedaż oferty własnego obiektu, atrakcji, imprezy nie w formie pakietowej, czyli współpraca z Biurem w celu sprzedaży miejsc noclegowych własnych obiektów, oferty gastronomicznej, atrakcji,

- kreowanie produktów - uczestniczenie w procesie budowania oferty produktowej - tworzenie pakietów - gestorzy indywidualni mogą bowiem samodzielnie tworzyć całościowe pakiety pobytowe lub zorganizowane pakiety wycieczkowe i sprzedawać je Biuru Promocji, które obuduje je jedynie ofertą przelotu i transferu do konkretnego obiektu, miejsca.

4. Firmy transportowe (państwowe i prywatne):

- transfer z lotniska - podjęcie długofalowej współpracy z firmami transportowymi, które będą miały za zadanie zapewnienie podróżnemu transportu z lotniska do miejsca docelowego pobytu lub dogodnego punktu przesiadkowego.

- Spółka lotnicza:

- współpraca w zakresie kreowania ruchu lotniczego - podjęcie długofalowej współpracy pomiędzy spółką zarządzającą lotniskiem a Biurem Promocji, opartej na ścisłych relacjach w zakresie sprzedaży biletów lotniczych. Biuro Promocji przejęłoby ciężar związany z wytworzeniem ruchu turystycznego na Warmię i Mazury w oparciu o komunikację lotniczą,

- współpraca w zakresie podnoszenia standardu obsługi - poprzez bezpośrednie relacje z rynkiem zewnętrznym Biura Promocji.

5. Touroperatorzy, biura podróży polskie i zagraniczne: 
- sprzedaż pakietów lub opcjonalnie sam przelot, pojedyncze produkty.

\section{Podsumowanie}

Region warmińsko-mazurski ma rozpoznawalną markę w kraju i zagranicą. Dużym sukcesem zakończyła się kampania promocyjna „Mazury Cud Natury”, która w wydatny sposób wpłynęła na poprawienie postrzegania walorów turystyczno-przyrodniczych Warmii i Mazur.

W ramach dofinansowania środkami Unii Europejskiej w regionie powstała sieć ponad 100 hoteli, które posiadają ponad 10 tysięcy miejsc noclegowych o wysokim standardzie świadczonych usług. Jednocześnie region cieszy się złą opinią dotyczącą słabej dostępności komunikacyjnej. Uruchomienie lotniska regionalnego może stać się szansą na wykorzystanie posiadanego potencjału. Aby jednak tak się stało należy podjąć działania zmierzające do:

- zbudowanie systemu współpracy branży turystycznej,

- powołanie regionalnego operatora produktu,

- powstanie i rozwój lokalnych produktów turystycznych,

- opracowanie 7 dniowych pakietów All Inclusive , HB i innych,

- określenie głównych kierunków przyjazdów turystów i oszacowanie ilości turystów zainteresowanych wycieczkami lotniczymi,

- dotarcie do biur podróży i przewoźników lotniczych,

- opracowanie nowego produktu turystycznego „Samolotem na Warmię i Mazury",

- wydanie wspólnego katalogu produktowego wycieczek lotniczych do regio$\mathrm{nu}$,

- opracowanie nowych lokalnych produktów turystycznych oferowanych w bazie hotelowej,

- wspólna promocja produktów turystycznych.

Działania te muszą zostać podjęte natychmiast i zostać zakończone najpóźniej do końca 2015 roku. Tylko wtedy będzie szansa, że po uruchomieniu lotniska uda się wdrożyć w życie nowy produkt turystyczny „Samolotem na Mazury”, z którego korzyści będzie mieć cały region. 


\section{Literatura}

Klimczak J., Żukowski M., Klimczak M., Perspektywy rozwoju ruchu turystycznego na Warmii i Mazurach poprzez wykorzystanie lotniska Szczytno-Szymany, Warszawa 2011.

W odniesieniu do „Strategii rozwoju sieci drogowej regionu warmińsko-mazurskiego” opracowanej przez Instytut Badawczy Dróg i Mostów w Warszawie.

Zgodnie $\mathrm{z}$ „Założeniami planu rozwoju infrastruktury komunikacji lotniczej $w$ województwie warmińsko-mazurskim" opracowanymi przez Zespół Roboczy ds. Infrastruktury Lotniczej, Olsztyn, kwiecień 2004.

Mitchell R.K., Agle B.R., Wood D.J., Toward a Theory of Stakeholders, „Academy of Management Review" 1997, t. 22.

\section{A Regional Airport as a Chance for Tourism Development in Warmia and Masuria}

\section{Summary}

A region's potential to attract both tourists and investments to a great extent depends on its accessibility and its transport infrastructure. Warmia and Masuria is a very attractive tourist destination. A new regional airport is supposed to stimulate further development of the region, facilitating greater and easier access for tourists both from Poland and abroad, and thus contributing to the further development of the tourism industry in the region. For this purpose a regional operator has been appointed to market the tourism product "To Masuria by Plane" and render its services to both tourists and local hotels.

Keywords: Tourism, tourism product, regional air port, regional tourism operator.

Translated by Katarzyna Cieplińska 